Atıf için / For Citation: Y. A. Üncü, G. Sevim, M. Canpolat, "Difüz optik tomografi sisteminde görüntü işleme uygulamalarının test edilmesi”, Süleyman Demirel Üniversitesi Fen Edebiyat Fakültesi Fen Dergisi, 16(1), 1-16, 2021.

\title{
Difüz Optik Tomografi Sisteminde Görüntü İşleme Uygulamalarının Test Edilmesi
}

\author{
Yiğit Ali ÜNCÜ*1, Gençay SEVİM², Murat CANPOLAT ${ }^{1}$ \\ ${ }^{1}$ Akdeniz Üniversitesi, Tip Fakültesi, Biyofizik Anabilim Dalı, 07058, Antalya, Türkiye \\ ${ }^{2}$ Eskisehir Teknik Üniversitesi, İleri Teknolojiler Anabililim Dall, 26555, Eskişehir, Türkiye
}

*yazışllan yazar e-posta: yuncu@akdeniz.edu.tr

(Alınış / Received: 13.11.2020, Kabul / Accepted: 22.12.2020, Yayımlanma / Published: 27.05.2021)

Özet: Sürekli Dalga Difüz Optik Tomografi (Continuous Wave Diffuse Optical Tomography, CWDOT) sistemi tıp alanında kullanılan görüntüleme sistemlerinden biridir. Bu çalışmanın amacı, CWDOT sistemi ile oluşturulan üç boyutlu (3B) meme fantomu görüntülerine farklı görüntü işleme yöntemlerini $3 \mathrm{~B}$ olarak uygulamak ve en uygun görüntü işleme yöntemini belirlemektir. Meme fantomu intralipid, su ve Indosiyanin yeşili (ICG) karışımında yapıldı, tümörü temsil etmesi için karışımın içine inklüzyonlar konuldu. Bu çalışmada, görüntü işleme algoritmalarında uzaysal filtrelerden (spatial filter); Ortalama, Gauss, Laplas, Laplasyen Gauss filtreleme yöntemleri uygulandı. Daha sonra, en yakın komşu, çift doğrusal, çift kübik ve kübik spline interpolasyon yöntemleri görüntülere uygulandı. Görüntü işleme sonuçları; Tepe sinyalinin gürültüye oranı (PSNR), Ortalama hata karesi (MSE) ve Yapısal benzerlik oranı (SSIM) yöntemleri kullanılarak sayısal karşılaştırmaları yapılmıştır. Bu çalışma ile tümör benzeri yapıların meme fantomu içindeki konumlarını gerçek şekil ve boyutlarda en iyi ortaya çıkaran görüntü işleme yöntemleri belirlendi. CWDOT sistemine uygun olan görüntü işleme yöntemlerinin Gauss filtreleme ve çift kübik interpolasyon yöntemleri olduğu gösterildi.

Anahtar kelimeler: Difüz optik tomografi, Görüntü işleme, Görüntü filtreleme, Görüntü interpolasyon

\section{On Testing Image Processing Applications in Diffuse Optical Tomography System}

Abstract: Continuous Wave Diffuse Optical Tomography (CWDOT) system is one of the emerging medical imaging modalities. This study aims to apply different three dimensional (3D) image processing methods to breast phantom images and determine the most appropriate image processing methods in CWDOT. A breast phantom was made with a mixture of intralipid, water, and Indocyanine green (ICG). Inclusions were used to represent the tumor inside the phantoms. First, image processing methods of spatial filters such as Average, Gaussian, Laplacian, Laplacian of Gaussian (LoG) filtering methods were implemented. Then, nearest, bilinear, bicubic, and cubic spline interpolation methods were applied to the images. After the image processing using different filters and interpolation techniques, the images were evaluated numerically using the Peak signal-to-noise ratio (PSNR), Mean square error (MSE), and Structural similarity index (SSIM) methods. In this study, the most appropriate image processing algorithm was defined based on the location, shapes, and sizes of the breast phantom inclusions. Our results show that Gaussian filtering and Bicubic Interpolation are the most appropriate filtering and interpolation techniques for the images obtained from CWDOT.

Key words: Diffuse optical tomography, Image processing, Image filtering, Image interpolation. 


\section{Giriș}

Görüntüleme yöntemleri tıp alanında oldukça geniş bir uygulama alanına sahiptir. Son yıllarda gelişen teknolojiye bağlı olarak baş, meme, gövde, karın, ayak, göz, yüz ve diş gibi vücudun çeşitli bölgelerinde medikal ölçüm, analiz ve araştırmalar yapılmaktadır. Tıbbi görüntüleme yöntemleri vücudun bir kısmını ya da tamamını kapsayan boyut, biçim, deformasyon ölçümlerini incelemektedirler. Bu yöntemlerden biri olan optik görüntüleme sistemleri; zaman tabanlı (time domain, TR), frekans tabanlı (frequency domain, FD) ve sürekli dalga (continuous wave, CW) olarak 3'e ayrilır [1]. Zaman tabanlı sistemlerde, 1 şık doku içerisinde yol aldıktan sonra fotonların zamansal dağılımı ölçülmektedir ve dokunun optik özellikleri derinliğe bağlı olarak belirlenmektedir [2-3]. Frekans tabanlı sistemlerde belirli frekans aralığında genlik modülasyonu yapılabilen sürekli 1şık kaynağı kullanılmaktadır [4]. Gönderilen 1şığa göre toplanan 1şık şiddeti ve faz kayması kullanılarak dokunun optik özellikleri belirlenmektedir [5]. Sürekli dalga sistemlerinde ise sabit şiddette 1şık dokuya gönderilmekte ve dokuda toplanan 1şı ğın şiddetindeki azalma miktarı ölçülerek dokulardaki optik özellikler incelenmektedir [56]. Bu sistemler, geri yansıma ve geçirgenlik geometrisinde kullanılmaktadır.

Son yıllarda kullanılan görüntüleme sistemlerinden biri olan Sürekli Dalga Difüz Optik Tomografi (Continuous Wave Diffuse Optical Tomography, CWDOT) sistemlerinde de görüntü oluşturma aşamalarında farklı yaklaşımlardan yararlanılmaktadır. CWDOT sistemlerinde görüntü oluşturma aşamasında çeşitli geri çatım algoritmaları kullanılmaktadır [6-7]. CWDOT sistemleri için kesikli eşlenik gradyent (TCG) algoritması gerçeğe yakın en iyi görüntüyü veren algoritmalardan biridir [7]. Tıbbi görüntüleme sistemlerinde de olduğu gibi CWDOT sistemindeki görüntüler, sistemin doğasından kaynaklı veya elektronik gürültü ve deney hataları gibi nedenlerden (gürültülerden) dolayı istenilen şekilde elde edilememektedir. Bu sistemlerde geri çatım teknikleriyle oluşturulan medikal görüntülerin, gerçeğe daha yakın oluşması için görüntülere ön işleme (pre-processing) ve ileri işleme (post-processing) gibi görüntü işleme teknikleri uygulanmaktadır [8-9].

Sayısal görüntülerdeki istenmeyen işaretleri yok etmek, görüntüyü zenginleştirmek, görüntüde istenilen ayrıntıların ortaya çıkarılmak ya da daha belirgin hale getirilmek için yapılan işlemlere filtreleme denilmektedir [8]. Filtreleme ile sayısal görüntüdeki piksellerin renk ve parlaklık değerleri çeşitli filtreleme operatörleri ile değiştirilmekte veya bozulan piksellerin değerleri yeniden hesaplanarak düzeltilmeye çalışılmaktadır.

Filtreleme işlemlerinde görüntü uzaysal filtre adı verilen bir sonlu darbe cevabı ve konvolüsyon işlemi ile gerçekleştirilir. Uzaysal filtreleme yerine konvolüsyon çekirdeği, konvolüsyon maskesi gibi isimler de kullanılır. Filtreleme işlemi görüntü üzerinde filtrenin boyutları oranında gezdirilerek görüntüdeki piksellerin değişimi ile yapılır. Farklı yöntemlere göre çeşitlilik gösteren piksel hesaplama işlemleri son değerini alarak yeniden hesaplanır. Bu hesaplanan piksel işlemi, kullanılan yöntemlere göre değişmekte (gürültü giderme, kenar keskinleştirme, görüntü yumuşatma vb.) ve komşu pikseller (ağırlıkları) dikkate alınarak yapılmaktadır [8-9].

Görüntü işleme filtreleri, uzaysal ortamda filtreleme ve frekans ortamda filtreleme olarak ikiye ayrılır. Uzaysal filtreleme, doğrusal ve doğrusal olmayan olarak iki çeşittir. Doğrusal filtreler konvolüsyon filtreleri olarak da bilinirler. Görüntü işlemede kullanılan başlıca doğrusal filtreler; yumuşatıcı, keskinleştiren, bulanıklaştırma filtreleri gibi filtrelerdir. Doğrusal olmayan filtreler ise medyan filtre, max filtresi ve min filtreleridir. Doğrusal ve doğrusal olmayan filtreler genelde gürültüyü azaltmak için kullanılır[9]. Çalışma kapsamında literatürde sık kullanılan uzaysal yumuşatıcı filtrelerden ortalama filtreleme, Gauss filtreleme ve keskinleştirici filtrelerden Laplas 
filtreleme, Laplasyen Gauss (LoG) filtreleme yöntemleri tasarlanarak CWDOT sistemine uygunluğu test edildi.

Tıbbi görüntüleme sistemlerinde lezyon, lezyon benzeri ve çeşitli anatomik yapıların (küçük olması durumlarında bile) net olarak görüntülenmesi gerekmektedir. Ayrıca görüntülerin büyütülüp ve/veya yeniden boyutlandırması durumunda görüntülerin bozulmaması gerekmektedir. 3B görüntülerde ise görüntülerin farklı açı ve yönlerde ( $\mathrm{x}$ $y, x-z, x-y-z)$ elde edilmesi ve analiz edilme işlemlerinde görüntü kontrastlarında meydana gelebilen olası değişiklikler beklenmedik bir durumdur. $\mathrm{Bu}$ yüzden görüntüleme sistemlerinde $2 \mathrm{~B}$ ve $3 \mathrm{~B}$ görüntüleri daha net hale getirebilmesi ve geometrik düzeltmelerinin yapılması için interpolasyon yöntemleri kullanılmaktadır. Sayısal analiz yöntemlerinde tanımlanan elde mevcut olan değer veri noktalarından yola çıkılıp, farklı bir yerde ve değeri bilinmeyen veri noktasının değerini bulan yöntemlerin tümüne interpolasyon yöntemleri denilmektedir [9].

$\mathrm{Bu}$ yöntemlerden en sık kullanılanları; en yakın komşu, doğrusal, çift kübik ve kübik spline yöntemleridir [8-9]. Bu yöntemler çalışma kapsamında tasarlanarak uygunluğu test edildi. $\mathrm{Bu}$ çalışmada, CWDOT sisteminde alınan veriler kullanılarak doku fantomları üzerinde ölçümler alındı ve TCG geri çatım algoritması ile görüntüler elde edildi. Daha sonra bu görüntüler üzerinde yukarıda bahsedilen faklı filtre ve interpolasyon kombinasyonları uygulanarak en iyi görüntüyü veren kombinasyon belirlendi. Görüntü işleme algoritmaların performanslarını karşılaştırmak ve en uygun kombinasyonu belirlemek için literatürde bir takım nicel ölçütler kullanılmaktadır [10]. Çalışma kapsamında Tepe sinyalinin gürültüye oranı (PSNR), Ortalama hata karesi (MSE) ve Yapısal benzerlik oranı (SSIM) yöntemleri kullanılarak görüntü işleme algoritmalarının performansları sayısal olarak değerlendirildi. CWDOT sistemlerine uygun filtreleme yöntemlerinden gauss filtresinin ve interpolasyon yöntemlerinden olan çift kübik yönteminin en uygun sonuç verdiği sayısal olarak gösterildi. Tasarlanan görüntü işleme yöntemleri MATLAB R2019b programlama dili ile gerçekleştirildi. Bu yöntemler ile CWDOT sisteminden elde edilen $2 \mathrm{~B}$ ve $3 \mathrm{~B}$ görüntülerine görüntü işleme teknikleri uygulanarak in-vitro çalışmalarında doğru ve hızlı sonuç verecek bir şekilde tasarlandi.

\section{Materyal ve Metot}

\subsection{Difüz optik tomografi sistemi}

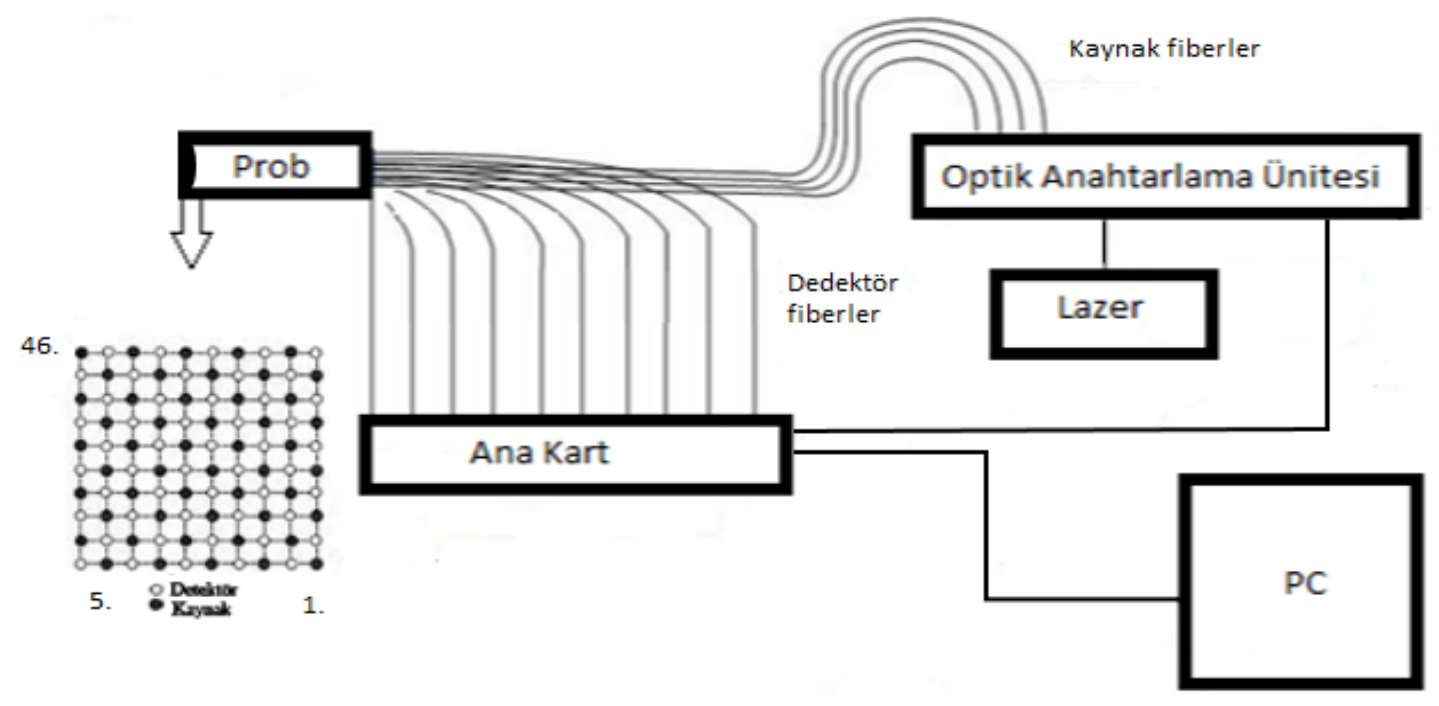

Şekil 1. Difüz optik tomografi sisteminin blok diyagramı 
Çalışmada kullanılan DOT cihazı, Akdeniz Üniversitesi, Tıp Fakültesi, Biyomedikal Optik Araştırma Ünitesi'nde daha önceden tasarlanmış olan CWDOT sistemidir [10]. CWDOT sistemi geri yansıma geometrisinde çalışmakta olup dokuya gönderilen 808 $\mathrm{nm}$ dalga boyunda 1şık doku içinde difüzyona uğramakta ve bir kısmı üst yüzeyden geri çıkmaktadır. Sistemde kullanılan 49 çıkışlı bir optik anahtarlama ünitesi ile lazer, 49 kaynak fibere yönlendirilmekte ve difüzyona uğradıktan sonra üst yüzeyden çıkan fotonlar 49 dedektör fiber tarafindan toplanarak foto diyotlara yönlendirilmektedirler [11].

Ayrıca prob üzerinde çapları $1 \mathrm{~mm}$ olan 49 tane kaynak fiber ve 49 tane dedektör fiber bulunmaktadır. $\mathrm{Bu}$ fiberler $10 \times 10^{\prime}$ luk bir matris şeklinde prob yüzeyine yerleştirilmiştir. Optik probun yüzey alanı $28 \times 28 \mathrm{~mm}^{2}$ olup, en yakın kaynak dedektör arası mesafesi 3 mm ve kaynak - dedektör eşleşmeleri Şekil 1' de gösterildiği gibidir. Probun yapısında 22 farklı kaynak dedektör mesafesi ve toplamda 2401 (49 × 49) eşleşme mevcuttur. Prob üzerinde en uzak komşular arasındaki mesafe ise 36,12 mm' dir (Şekil 1). Doku ve/veya doku benzeri ortama gönderilen lazer, dedektör fiberler tarafinda toplanmakta ve foto diyotlara gönderilmektedir [11].

Geri yansıyan 1şık, dedektör fiberler ile foto diyotlara iletilir. Gelen 1şığın şiddetine bağlı olarak foto diyotların ürettiği akımlar integral alıcı devre ile gerilime çevirirler. Bu sistemde bir kaynak fiberden 1 şık gönderilirken aynı anda tüm dedektör fiberlerinden geri yansıyan ışı toplanır. Toplanan veriler, daha sonra homojen ortamdan alınan ölçüm ile aralarındaki ışı şiddeti değişimi (pertürbasyon verileri) hesaplanır. Bu pertürbasyon verileri geri çatım algoritmalarında kullanılıp görüntü oluşturulur[11].

\subsection{Deney Seti}

Çalışma kapsamında, CWDOT sistemi ile meme dokusu eşdeğeri ortamda in-vitro deneyler yapıldı. İlk olarak, probun hizasına getirilen inklüzyon ve/veya inklüzyonların, intralipid (yağ emülsiyonlarından meydana gelen karışım) içinde ölçülmesi amaçlandı. Deneyler için tasarlanan meme fantomu $28 \times 18 \times 12 \mathrm{~cm}^{3}$ hacmindedir. Bu fantomun üst tarafında, CWDOT sisteminin probuna uygun şekilde tasarlanmış bir boşluk mevcuttur (Şekil 2).

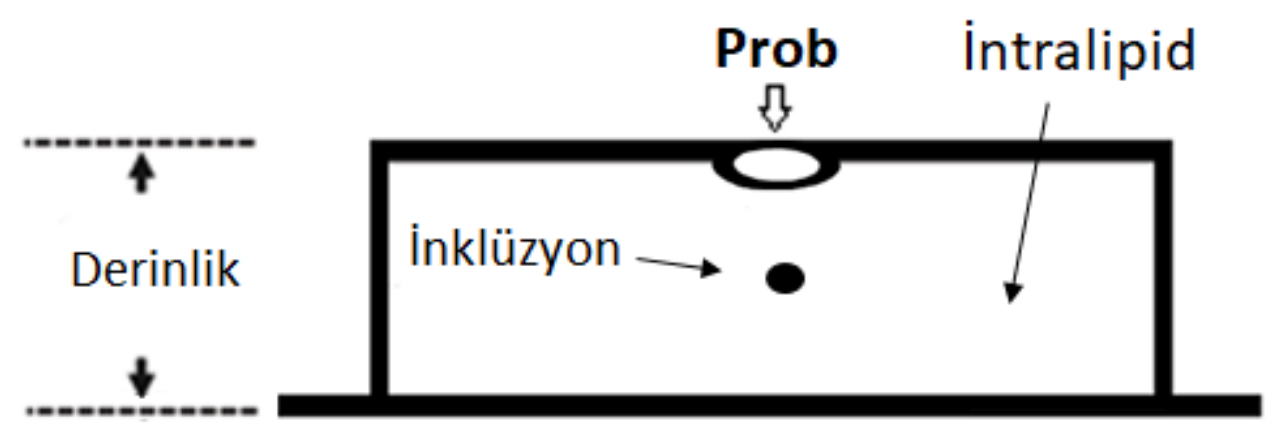

Şekil 2. İnklüzyon deney setinin blok diyagramı

$\mathrm{Bu}$ deneylerde meme fantomu için $5000 \mathrm{ml}$ olacak şekilde intralipid ve ICG - su karışımı hazırlandı [12]. Hazırlanan bu karışımın absorbsiyon katsayısı $0,004 \mathrm{~cm}^{-1}$ olup 1şı̆̆ı saçma katsayısı $10 \mathrm{~cm}^{-1}$ dir. Daha sonra meme dokusuna göre absorbsiyon katsayısı daha yüksek olan tümörlü yapıya benzer bir yapı olan inklüzyonun absorbsiyon katsayıs1, ICG konsatrasyonu dört kat artırılarak $0,016 \mathrm{~cm}^{-1}$ yapıld1. Hazırlanan deney setinin şematik görüntüsü Şekil 2'de gösterildiği gibidir. Tasarlanan 
deney seti, homojen meme doku eşdeğeri bir ortamdır. Bu deneydeki memedeki tümörü temsil eden yapılar (inklüzyonlar), intralipid çözeltisine konularak gerçekleştirildi. İmtralipid deneylerinde homojen bir ortamdan (intralipid - ICG çözeltisi) kalibrasyon ölçümleri alındı. Daha sonra hazırlanan fantomun içerisine farklı derinlik, boyut ve farklı mesafelerdeki inklüzyonlar konularak CWDOT ile ölçümler yapıldı. Sistemde kalibrasyon ölçümüyle inklüzyon görüntülemek için yapılan ölçümün farkı (kontrast farkı) absorbsiyon farkını belirmektedir. Bu absorbsiyon farkı geri çatım algoritmasında (TCG) girdi olarak kullanıldı ve içinde inklüzyon olan meme fantomunun 3B görüntüsü elde edildi. Daha sonra oluşan görüntülere görüntü işleme yöntemleri uygulandı.

\subsection{Görüntü İşleme Yöntemleri}

$\mathrm{Bu}$ çalışmada CWDOT ile meme fantomları üzerinde alınan veriler TCG geri çatım algoritması kullanılarak 3B görüntüler oluşturuldu. İlk adımda medikal görüntü işleme yöntemlerinden olan filtreleme kısmında literatürde sık kullanılan uzaysal filtrelerden; Ortalama filtreleme, Gauss filtreleme, Laplas filtreleme, LoG filtreleme yöntemleri çalışmada kullanılmak için seçildi [4]. İkinci adımda literatürde sık kullanılan interpolasyon yöntemleri olan en yakın komşu interpolasyon, çift doğrusal interpolasyon, çift kübik interpolasyon ve kübik spline interpolasyon yöntemleri [13-15] 3B olarak uygulanmak için yeniden tasarland.

Kullanılan görüntü işleme algoritmaların performanslarını karşılaştırmak için PSNR, MSE ve SSIM yöntemleri kullanılarak görüntü işleme algoritmalarının performansları sayısal olarak değerlendirildi. Çalışmada kullanılan filtreleme ve interpolasyon yöntemleri ile bu yöntemleri ve de performanslarını belirlemek için kullanılan sayısal ölçüt yöntemleri sırası ile aşağıda anlatılmaktadır.

\subsubsection{Filtreleme Yöntemleri}

Yumuşatıcı filtrelerden olan ortalama filtreleme, görüntüleri yumuşatmak için kullanılan en basit olan ve kolay uygulanan yöntemlerden bir tanesidir. Bu yöntem görüntüdeki bir piksel ile bir diğer piksel arasındaki değişim miktarını azaltmaktır. Ortalama filtreme, bir görüntünün bir piksel değerini kendisinin ve komşularının olduğu ortalama bir değer ile değiştirerek hesaplama yapan bir yöntemdir. Ancak bu hesaplama, çevresindekileri temsil etmeyen piksel değerlerinin ortadan kaldırılmasına yol açmaktadır. Ortalama filtresi bir konvolüsyon filtresi olarak çekirdek filtreleme temeline dayanır ve genellikle görüntülerdeki gürültüyü azaltmak için kullanılır.

$$
g(x, y, z)=\frac{\sum_{i=-l / 2}^{l / 2} \sum_{j=-m / 2}^{m / 2} \sum_{k=-n / 2}^{n / 2} h(i, j, k) f(x+i, y+j, z+k)}{g(x, y, z)=\sum_{i=-l / 2}^{l / 2} \sum_{j=-m / 2}^{m / 2} \sum_{k=-n / 2}^{n / 2} h(i, j, k)}
$$

Denklem 1' de $1, \mathrm{~m}$ ve $\mathrm{n}$ sırasıyla $\mathrm{x}, \mathrm{y}, \mathrm{z}$ yönlerindeki görüntü boyutları, $\mathrm{h}$ filtre çekirdeği, f değeri TCG sonrası elde edilen görüntüdür. Seçilen filtreleme ile görüntünün her bir piksel değeri kendisinin ve komşularının olduğu ortalama değer ile değiştirilmektedir.

Ortalama filtreleme yönteminin Gauss dağılımı kullanılarak biraz daha değiştirilmiş hali Gauss filtreme olarak bilinmektedir [16]. Bu yumuşatıcı filtreleme yönteminde, Gauss dağılım fonksiyonu kullanılarak filtrenin standart sapma değerinin genişliğine bağlı bir çekirdek üretilir. Gauss filtreleme yöntemi görüntüde her piksel bölgesinin ağırlıklı ortalamalarını çıkararak merkez piksel değerine doğru yaklaştıkça ağırlıklandırmayı giderek artırır. Bu durum, ortalama filtreme yöntemine (her yeri eşit ağırlıklandırma 
yapar) göre daha hassas bir düzeltme yaparak görüntüdeki veri geçişlerinin daha yumuşak hale getirilmesini sağlar $[8,16]$. Böylelikle görüntüde düzleştirme sağlayan ve bulanıklık etkisi oluşturan alçak geçiren bir filtre elde edilir. Bu filtrenin bulanıklık etkisi $\sigma$, standart sapma ile belirlenir. Bu etki ile ortalama filtrelerde olduğu gibi taneli yapıda olan gürültüler görüntüden kaldırabilir. Filtre yapısı sayesinde düzleştirme etkisi kuvvetlidir. Ǘç boyutlu Gauss dağılımı yöntemi Denklem 2' de gösterildiği gibidir.

$$
G(x, y, z)=\frac{1}{\sqrt{2 \pi} \sigma^{3}} \exp ^{\left(-\left(\frac{x^{2}+y^{2}+z^{2}}{2 \sigma^{2}}\right)\right)}
$$

CWDOT sisteminde 3B olarak tasarlanan Gauss filtresi kullanıldı. Bu filtre Denklem 2' de belirtildiği gibi $\mathrm{x}, \mathrm{y}, \mathrm{z}$ koordinatlarındaki görüntü $\mathrm{G}(\mathrm{x}, \mathrm{y}, \mathrm{z}), 5 \times 5 \times 5$ boyutunda filtre (pencere) genişliği ve standart sapma değeri $(\sigma=1)$ olmak üzere 3B olarak tasarlandı [11]. Bu tasarlanan filtre sayesinde görüntüler için aynı doğrulukta sonuç veren, gürültüden arındırılmış ve yumuşatılmış bir görüntü elde edilmesi amaçlandı. Gauss filtreleme, görüntülerde sonsuz bir transfer fonksiyonuna karşılık mekansal alanda sonlu bir filtre penceresinde (tarama penceresi) filtreleme yapilabilmektedir. Bu da filtrenin temel problemini daha kolay çözülebilir hale getirerek kullanım alanlarını artırmaktadir [8-9].

Gauss filtrenin düzgünleştirme etkisi, bir görüntüyü ortalama filtreye benzer şekilde bulanıklaştırabilir. Filtrenin düzeltme derecesi Gauss filtresinin standart sapması ile belirlenmektedir. Daha büyük standart sapma değeri, gauss fonksiyon grafiğini daha geniş hale getirmektedir. Bundan türetilen filtre çekirdeği görüntü matrisinde Gauss eğrisinin doğru olarak temsil edebilmesi için daha büyük boyutta $(5 \times 5 \times 5)$ seçildi.

Keskinleştirici filtrelemelerden olan Laplas ve LoG filtrelemeler, görüntülerdeki kenar geçişlerini ve hatlarını belirlemek için kullanılmaktadır. Burada görüntü kenarı ile kastedilen, objeleri görüntünün arka planından ayıran keskin geçişlerdir. Laplas doğrusal bir operatördür. İkinci dereceden türevi temsil eder ve Laplas yönteminin doğrudan kullanımı yerine daha genel olan LoG yöntemi kullanılır. LoG yöntemi görüntü zenginleştirerek görüntü kenar geçişlerini yakalamak için kullanılmaktadır. Görüntülerdeki hızlı değişiklikleri tespit edilmesinde etkili bir yöntemdir [8].

LoG yönteminde, Gauss alçak geçiren filtreleme kullanılarak görüntüdeki geçiş yumuşatılır. Görüntünün direk laplasyanını almak görüntülerde gürültüyü daha fazla artırabilir. $\mathrm{Bu}$ durum görüntüde istenmeyen birçok kenar noktasının ve gürültünün oluşmasına neden olacaktır. LoG yöntemi, görüntünün bir Gauss fonksiyonu ile konvolüsyonu sonrasında laplasyanı hesaplanarak gerçekleştirilir. Sıfır merkezli $(0,0)$ ve Gauss standart sapmasına sahip LoG yöntemi Denklem 3'de gösteriliği gibidir.

$$
\operatorname{LoG}(x, y, z)=\frac{-1}{\pi \sigma^{4}}\left[1-\frac{x^{2}+y^{2}+z^{2}}{2 \sigma^{2}}\right] \mathrm{e}^{-\frac{x^{2}+y^{2}+z^{2}}{2 \sigma^{2}}}
$$

$\mathrm{Bu}$ yöntemde standart sapma değeri $(\sigma)$ değiştirilerek filtrenin iyileştirme ve düzeltme miktarı kontrol edilebilmektedir. Görüntüde piksel yoğunluğu değerleri $\mathrm{x}, \mathrm{y}, \mathrm{z}$ koordinatlarında olan görüntünün Laplasyanı Denklem 3' de gösterildiği gibidir [8].

\subsubsection{Interpolasyon Yöntemleri}

CWDOT sisteminde, içinde inklüzyon bulunan meme fantomunda alınan verilere filtreleme işlemleri sonrası 3B interpolasyon yöntemleri uygulanarak görüntülerin gerçekçi boyutlarda ve net bir şekilde elde edilmesi amaçlandı. Bu kısımda en yakın komşu interpolasyon, çift doğrusal interpolasyon, çift kübik interpolasyon ve kübik spline interpolasyon yöntemleri 3B olarak CWDOT sisteminde uygulandı ve test edildi. 
İnterpolasyon yöntemlerinden en yakın komşu interpolasyon yönteminde, en yakın piksel belirlenir ve bu pikselin değeri girdi pikseline atanır. Hesaplama yönünden hızlı ve etkili olan bu yöntem, yeniden örnekleme sırasında piksel değerlerini değiştirmediğinden, tıbbi görüntüleme çalışmalarında tercih edilmektedir. Bu yöntemin avantaj1, diğer interpolasyon yöntemlerinin aksine piksel değeri hesaplanacak koordinatın komşularının ağırlıklı ortalamalarını almadan sadece en yakın piksel değerini tekrarlamasıdır. Bu yüzden komşu piksellerde oluşabilecek uç değerler ve ince ayrıntılar kaybolmamaktır.

Çift doğrusal interpolasyon yöntemi birinci dereceden interpolasyon olarak bilinmektedir. Çift doğrusal interpolasyonda, çıktı pikseline en yakın dört piksel belirlenerek bu dört pikselin değerlerine göre ağırlıklı ortalamaları atanır. Girdi görüntüsündeki dört pikselin değerinin ortalaması yeni hesaplanacak pikselin çıktı görüntüsündeki değerini belirler. Ortalama alma işlemi, girdi görüntüsündeki piksel değerlerini değiştirerek çıktı görüntüsündeki yeni değerlere atar.

Çift kübik interpolasyon yöntemi, hesaplama açısından diğer yöntemlere göre biraz daha karmaşıktır. Görüntüdeki herhangi konumdaki piksel değerini tahmin etmek için en yakınındaki (girdi görüntüsündeki) on altı en yakın piksel komşusunu işleme dahil eden bir yöntemdir. En yakın on altı komşu pikselin değerlerinin ortalaması hesaplanarak çıktı görüntüsündeki değerlere atanır.

Kübik spline interpolasyon yöntemi hesaplama açısından çift kübik yöntemine benzemektedir. Kübik spline interpolasyon yöntemi bütün piksellerde ikinci derece türev alma işlemi gerektirdiğinden işlem hızı ve gereksinim duyulan depolama alanı bakımından dezavantajlı bir yöntemdir. Ayrıca bu yöntem, çift kübik interpolasyondan farklı olarak fonksiyonda düğüm noktası olmayan uç koşulları kullanarak interpolasyon eğrisini daha düzgün hale getirip bazı veri kayıplarına yol açmaktadır [8-9].

\subsection{Performans Kriterleri}

Görüntü işleme algoritmalarının görüntüler üzerindeki etkileri öznel (görsel) ve nesnel (sayısal) olmak üzere iki şekilde değerlendirilebilir. Öznel değerlendirme sadece görsel olarak görüntülerin karşılaştırılması, değerlendirilmesi anlamına gelir. Kullanılan görüntü işleme algoritmalarının başarılarının değerlendirilmesi görsel olarak yapılabilir. Fakat görsel karşılaştırmalar öznel ve kişiye bağlı olabilir. Nesnel değerlendirmede ise belirli matematiksel modellere dayanan ölçüm yöntemleri kullanılmaktadır. Matematiksel yöntemlerde sonuçlar herkes için aynı şeyi ifade ettiği için görüntü kalitesinin ölçümü ve kullanılan algoritmanın başarısının değerlendirmesi için daha uygundur.

Görüntü işleme yöntemlerinin uygulanması sonucu elde edilen yeni görüntünün, girdi görüntüye ne kadar benzediğinin ölçülmesi sayısal yöntemler olan performans kriterleri ile yapılmaktadır. $\mathrm{Bu}$ nedenle görüntü işleme algoritmaların performanslarını karşılaştırmak için birtakım sayısal ölçütler kullanılmaktadır. Bu sayısal ölçütlerin başında tepe sinyalinin gürültüye oranı (PSNR), ortalama hata karesi (MSE) ve yapısal benzerlik oranı (SSIM) yöntemleri sayısal karşılaştırmalar için kullanıldı. MSE gerçek görüntü ile filtrelenen görüntünün karşılıklı bütün piksel değerlerinin farkların karelerinin toplamının ortalamasını vermektedir.

$$
M S E=\frac{1}{M N} \sum_{X=0}^{M-1} \sum_{y=0}^{N-1}\|g(x, y)-h(x, y)\|^{2}
$$

MSE, hata olarak filtrelenen görüntünün gerçek görüntüden ne kadar farklı olduğunu ölçmektedir. Denklem 4' e göre; $\mathrm{g}(\mathrm{x}, \mathrm{y})$ girdi görüntünün veri matrisi, $\mathrm{h}(\mathrm{x}, \mathrm{y})$ filtrelenen 
görüntünün veri matrisi, $\mathrm{M}$ görüntüdeki piksellerin satır sayısını $\mathrm{N}$ ise görüntüdeki piksellerin sütun sayısını ifade etmektedirler. Renkli görüntülerde MSE her bir renk kanalı için ayrı ayrı hesaplanmaktadır [4, 8].

PSNR, sinyalin alabileceği en fazla değer ile bozulan sinyalin kalitesini temsil eden değerin oranını ifade etmektedir. PSNR ne kadar yüksekse görüntü kalitesinin o kadar iyi olduğu söylenebilir. Görüntüdeki birçok sinyal geniş bir dinamik genişliğe sahip olduğundan, PSNR genellikle logaritmik olarak ifade edilir. PSNR' nin matematiksel ifadesi Denklem 5'de aşağıda gösterildiği gibidir.

$$
P S N R=20 \log _{10}\left(\frac{\operatorname{Max}_{f}}{\sqrt{M S E}}\right)
$$

Denklem 5'de $\mathrm{Max}_{\mathrm{f}}$, girdi görüntüdeki piksellerin alacağı maksimum değeri göstermektedir [9, 10]. Yüksek PSNR, filtrelenen görüntünün girdi görüntüye daha çok yakınsadığını ifade etmektedir. Bunun olması için MSE hatasının olabildiğince küçük olması gerekmektedir. Aynı iki görüntünün MSE hatasını hesaplamak istendiğinde sonuç sıfır olacaktır. Denklem 5'de denklemi sıfıra bölme durumunda ise denklemin sonucu tanımsız olacaktır. Bu durum PSNR' nin dezavantajıdır.

SSIM ise görüntülerin birbirine olan benzerliklerini ölçmek için kullanılan bir yöntemdir. Bir görüntünün bir diğerine benzerliğinin ölçülmesi için referans olarak gürültüsüz olan ya da görüntü işleme öncesindeki görüntüler kullanılmaktadır [10]. Sayısal karşılaştırma yöntemlerinden olan PSNR ve MSE' nin insan göz algısına uygun olmadığı bilinmektedir. SSIM ise bu geleneksel yöntemleri geliştirmek için oluşturulmuştur. Örneğin bulanık görüntüler insan gözü tarafından kalitesiz şekilde algılanmaktadır. Bu durum MSE ile ölçülememekle birlikte, SSIM ölçümlerinde gözlenebilir. PSNR ve MSE görüntülerde algılanabilir hataları tahmin eden yaklaşımlardır. SSIM ise görüntüdeki bozulmaları yapısal bilgideki (birbirlerine yakın pikseller) algılanan değişiklik olarak dikkate alır. Örneğin $\mathrm{M} \times \mathrm{N}$ boyutunda, $\mathrm{g}$ (benzerliği yapılacak görüntü) ve $r$ (referans görüntüsü) olarak iki farklı görüntü Denklem 6' de belirtildiği gibi hesaplanmaktadır.

$$
\operatorname{SSIM}(g, r)=\frac{\left(2 \mu_{g} \mu_{r}+c_{x}\right)\left(2 \sigma_{g r}+c_{y}\right)}{\left(\mu_{g}^{2}+\mu_{r}^{2}+c_{x}\right)\left(\sigma_{g}^{2}+\sigma_{r}^{2}+c_{y}\right)}
$$

$\mu_{\mathrm{g}}$ ve $\mu_{\mathrm{r}}$ görüntülerin ortalama değerleri, $\sigma_{g}^{2}$ ve $\sigma_{r}^{2}$ görüntülerin varyansları, $\sigma_{g r}$ görüntüler arasındaki kovaryansı göstermektedir. $c_{x}, c_{y}$ ise paydaların 0'a yaklaşıp formülün hatalı çıkmaması için kullanılan sabitlerdir. Burada, $c_{x}=\left(k_{x} L\right)^{2}, c_{y}=$ $\left(k_{y} L\right)^{2}$ ifade edilirken, $L$ değeri, görüntüdeki piksellerin alacağı en yüksek değerdir. $k_{x}$ ve $k_{y}$ değerleri sirasıyla 0.01 ve 0.03 değerlerini alan sabitlerdir. SSIM değerleri - 1 ile 1 arasında değerlik almaktadır. Örneğin karşılaştırılan iki görüntü aynı ise SSIM değeri 1 değerini alır. SSIM değeri 1' e ne kadar yakın ise görüntü kalitesinin o kadar iyileştiği anlaşılmaktadır [10].

\section{Bulgular}

Çalışma kapsamında meme fantomu üzerinde alınan CWDOT verileri TCG algoritmasında kullanılarak oluşturulan görüntülere yukarıda sözü edilen filtreleme ve interpolasyon yöntemleri uyguland. Görüntü işleme yöntemlerinin sayısal karşılaştırmaları 5. kaynağın hizasındaki inklüzyon görüntüsüne uygulandı. Uygulanan filtreleme ve interpolasyon yöntemlerinin PSNR, MSE ve SSIM sonuçları sayısal olarak karşılaştırılıp Tablo 1' de gösterildi. Sayısal sonuçlar dikkate alındığında, filtreleme 
yöntemlerinden Gauss filtreleme ve interpolasyon yöntemlerinden çift kübik interpolasyon yöntemleri diğer yöntemlere göre daha iyi çıkmıştır.

Tablo 1. 5. Kaynağın hizasındaki inklüzyon görüntüsüne uygulanan görüntü işleme yöntemlerinin sayısal olarak karşılaştırılması

\begin{tabular}{ccccc}
\hline Filtreleme Yöntemleri & İnterpolasyon Yöntemleri & PSNR & MSE & SSIM \\
& En yakın Komşu & 6,8836 & 276,6044 & 0,0042 \\
& & & \\
Çift Doğrusal & 7,0290 & 276,9582 & 0,0236
\end{tabular}

Ortalama

$$
\text { Çift Kübik } \quad 6,9618 \quad 277,0046 \quad 0,0255
$$

\begin{tabular}{crrr} 
Kübik Spline & 6,9176 & 276,9451 & 0,0244 \\
\hline En Yakın Komşu & 8,8632 & 239,4082 & 0,0134 \\
& & & \\
Çift Doğrusal & 9,0677 & 240,6231 & 0,0411
\end{tabular}

\begin{tabular}{cccc} 
Çift Kübik & $\mathbf{9 , 0 5 6 5}$ & $\mathbf{2 3 6 , 1 0 7 9}$ & $\mathbf{0 , 0 4 3 8}$ \\
& & & \\
Kübik Spline & 9,1612 & 235,0246 & 0,0437 \\
\hline En Yakın Komşu & 12,0319 & 489,6271 & 0,0018 \\
& & & \\
Çift Doğrusal & 13,9574 & 494,1084 & 0,0064
\end{tabular}

Laplas

Çift Kübik $\quad 12,9590 \quad 433,2762 \quad 0,0184$

\begin{tabular}{cccc} 
Kübik Spline & 10,2582 & 454,5854 & 0,0105 \\
\hline En Yakın Komşu & 9,2079 & 437,2002 & 0,0036 \\
& & & \\
Çift Doğrusal & 9,8525 & 420,1773 & 0,0437
\end{tabular}

LoG

\begin{tabular}{cccc} 
Çift Kübik & 10,2480 & 442,1759 & 0,0532 \\
Kübik Spline & 10,4895 & 446,7939 & 0,0530 \\
\hline
\end{tabular}

Deneylerde ve sayısal karşılaştırmalar ile uygunluğu test edilen Gauss filtreleme ve sonrasında çift kübik interpolasyon yöntemleri geri çatım algoritması (TCG) sonrası uygulanarak çalışma kapsamındaki tüm deneylerde inklüzyon görüntüleri oluşturuldu. Bu görüntülerin boyutları; $\mathrm{x}$, y ve $\mathrm{z}$ yönlerinden $39 \times 39 \times 24 \mathrm{~mm}^{3}$, piksel boyutları ise $0.26 \times 0.26 \times 0.24 \mathrm{~mm}^{3}$, voksel sayısı $15 \times 15 \times 10$ 'dur. Çalışma kapsamındaki deneylerde, inklüzyonlar farklı kaynaklar hizasında farklı konumlarda görüntülenebilmesi test amacıyla yapıldı. Bunun için ilk olarak, CWDOT sistemindeki probun 5. kaynağının hizasında yaklaşık olarak $5 \mathrm{~mm}$ derinliğe, çapı $5 \mathrm{~mm}$ olarak 
hazırlanan küresel bir inklüzyon yerleştirildi. Mevcut inklüzyonun gerçek boyutu görüntüler üzerinde kesikli çizgiler ile Şekil 3' te görülmektedir.

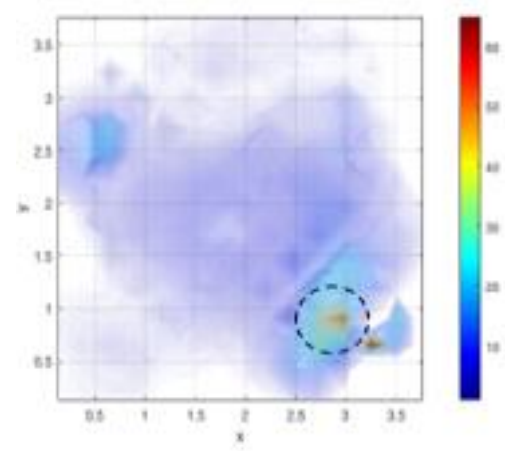

A)

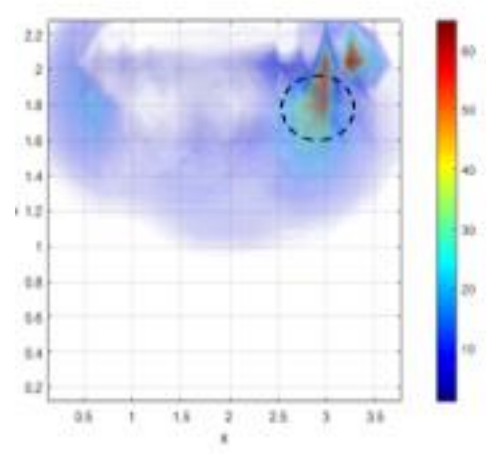

c)

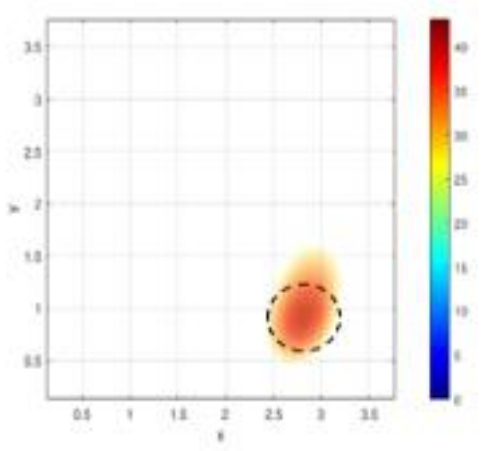

B)

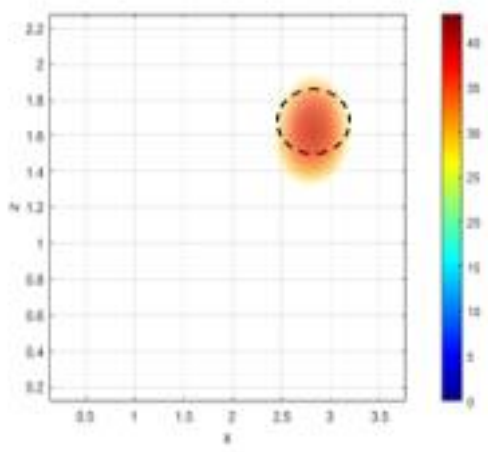

D)

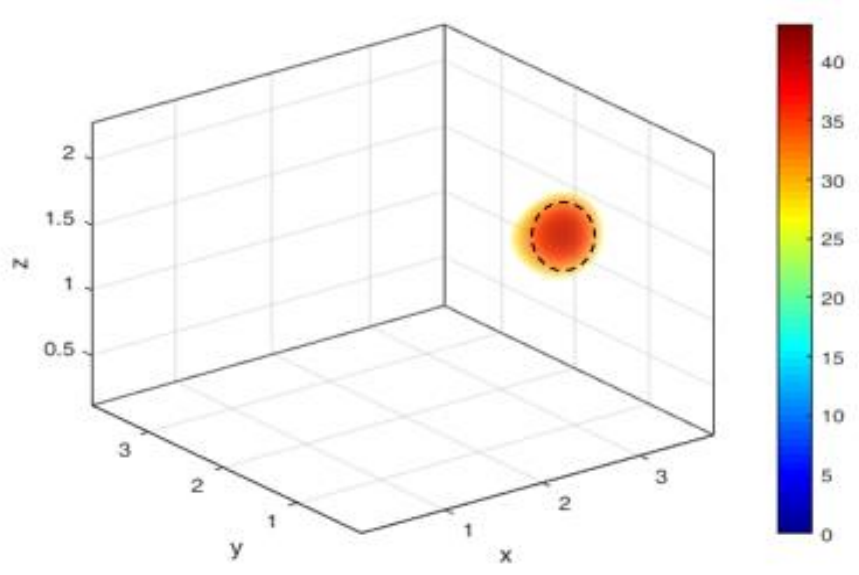

Şekil 3. 5. kaynağın hizasında küresel inklüzyonun A) TCG algoritması ile oluşturulan x-y yönündeki inklüzyon görüntüsü, B) TCG algoritması ile oluşturulan x-z yönündeki inklüzyon görüntüsü, C) Görüntü işleme sonrası oluşturulan $x-y$ yönündeki inklüzyon görüntüsü, D) Görüntü işleme sonrası oluşturulan $x-z$ yönündeki inklüzyon görüntüsü, E) Görüntü işleme sonrası 3B olarak oluşturulan inklüzyon görüntüsü.

İnklüzyon deneyinin ikinci kısmı, önceki deneyden farklı bir konumda olan inklüzyonun konumunu ve şeklini doğru belirlemek için yapıldı. Probun 46. kaynağının hizasında yaklaşık olarak $5 \mathrm{~mm}$ derinlikte, çap1 $5 \mathrm{~mm}$ olarak hazırlanan küresel bir inklüzyon yerleştirildi ve mevcut inklüzyonun gerçek boyutu görüntüler üzerinde kesikli çizgiler ile Şekil 4'te görülmektedir. 


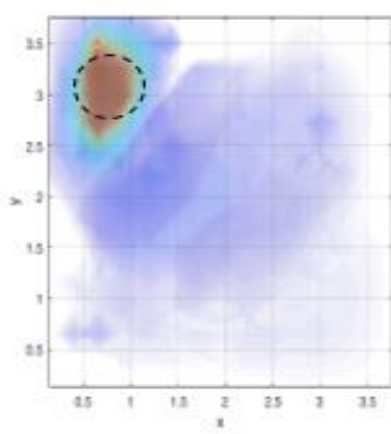

A)

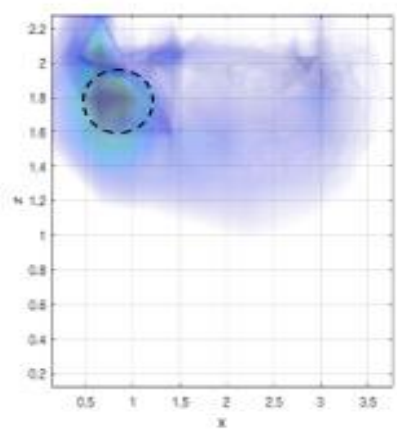

c)

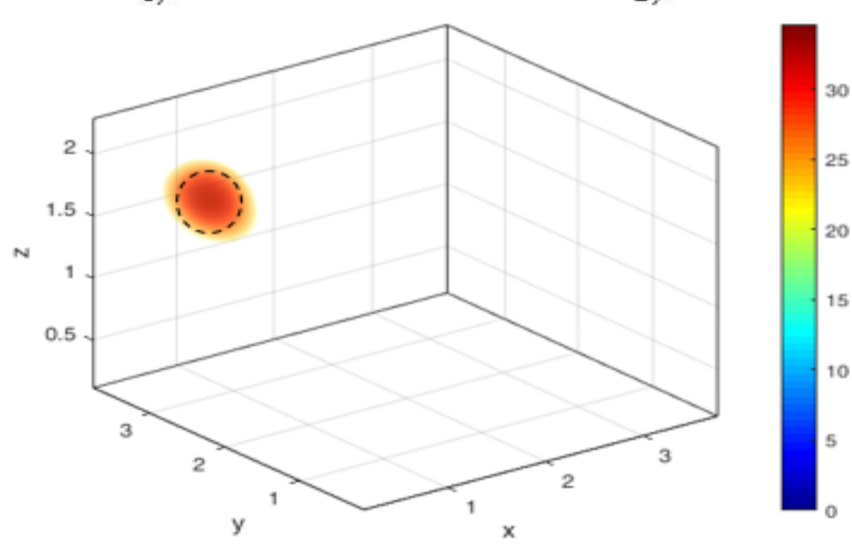

B

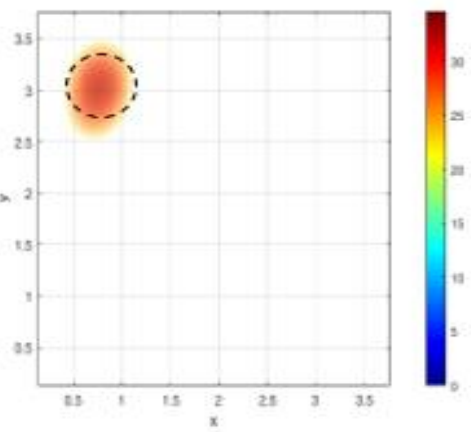

B)

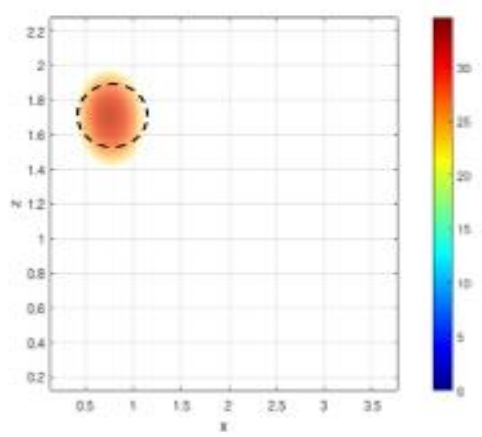

D)

)

Şekil 4. 46. kaynağın hizasında küresel inklüzyonun A) TCG algoritması ile oluşturulan x-y yönündeki inklüzyon görüntüsü, B) TCG algoritması ile oluşturulan x-z yönündeki inklüzyon görüntüsü, C) Görüntü işleme sonrası oluşturulan $x-y$ yönündeki inklüzyon görüntüsü, D) Görüntü işleme sonrası oluşturulan $x-z$ yönündeki inklüzyon görüntüsü, E) Görüntü işleme sonrası 3B olarak oluşturulan inklüzyon görüntüsü.

Deneyin bir sonraki kısmı, önceki deneylere göre daha derindeki inklüzyonun konumunu ve şeklini doğru tespit etmek için yapıldı. Probun ortasına gelecek şekilde yaklaşık olarak $8 \mathrm{~mm}$ derinliğe, yaklaşık $10 \mathrm{~mm}$ çapında bir inklüzyon yerleştirildi ve mevcut inklüzyonun gerçek boyutu görüntüler üzerinde kesikli çizgiler ile Şekil 5' te görülmektedir. 


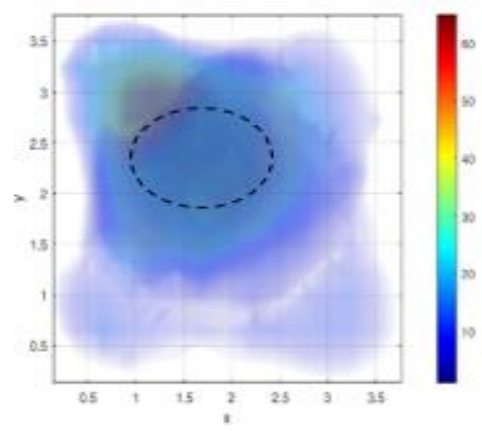

A)
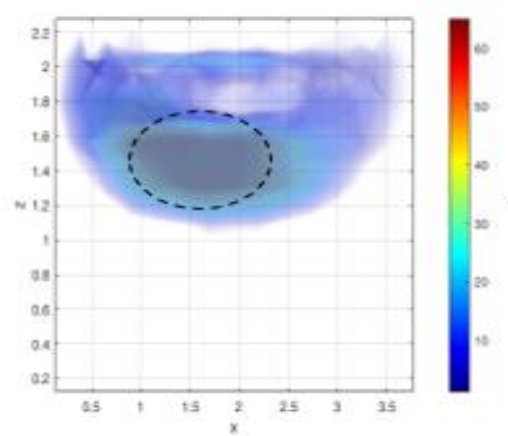

c)

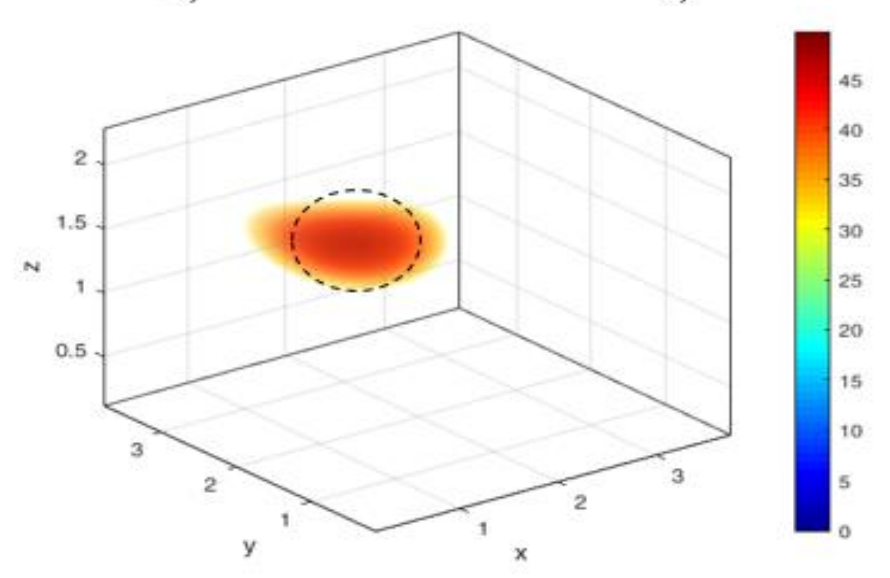

B)

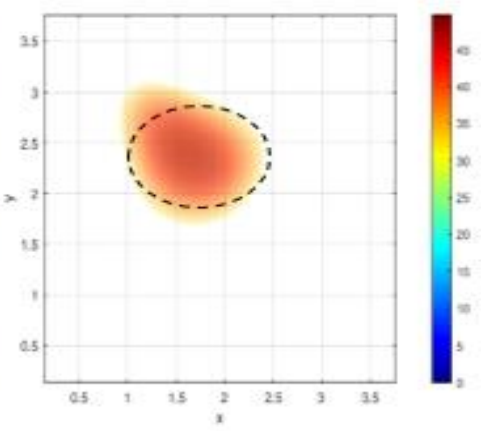

B)

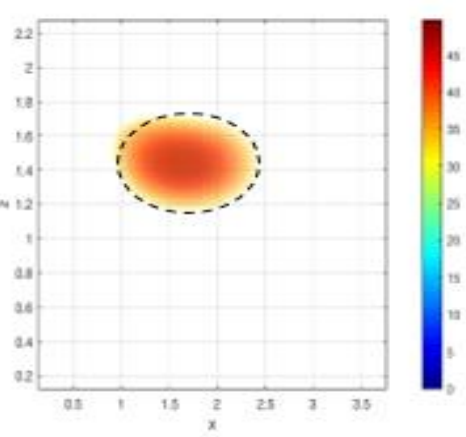

D) 


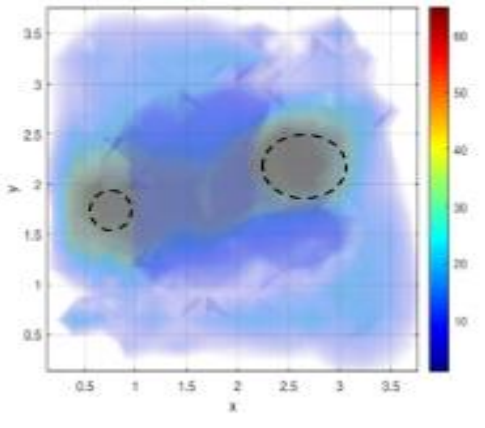

A)

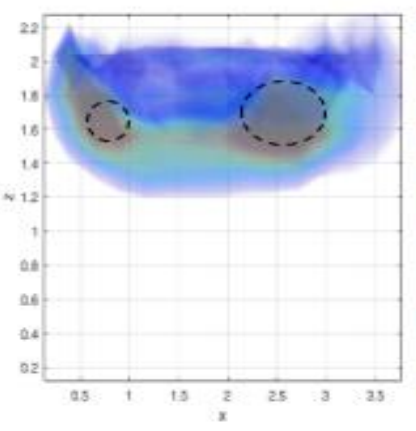

c)

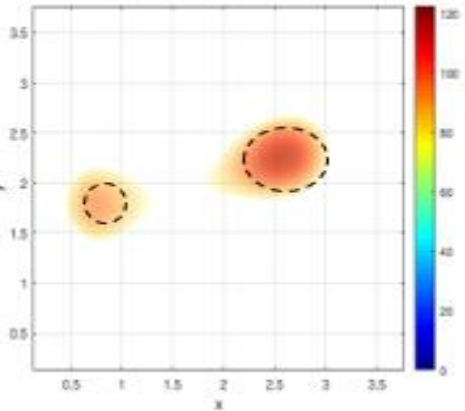

B)



D)



E)

Şekil 6. Farklı boyutlarda iki farklı inklüzyonun $7 \mathrm{~mm}$ derinlikte A) TCG algoritması ile oluşturulan x-y yönündeki görüntüsü, B) Görüntü işleme sonrası oluşturulan x-z yönündeki inklüzyon görüntüsü, C) TCG algoritması ile oluşturulan x-y yönündeki görüntüsü, D) Görüntü işleme sonrası oluşturulan x-z yönündeki görüntüsü, E) Görüntü işleme sonrası 3B olarak oluşturulan görüntüsü.

\section{Sonuç ve Yorum}

Gelişen teknoloji ile birlikte görüntü işleme uygulamalarının tıp alanında kullanımı gün geçtikçe artmaktadır. Bu duruma paralel olarak tıbbi görüntüleme alanında görüntü işleme tekniklerinin kullanımı da yaygınlaşmaktadır. Tıbbi görüntüleme yöntemlerinde görüntülerin elde edilmesi sırasında ve sonrasında görüntü işleme yöntemleri kullanılmaktadır. Optik görüntüleme sistemlerinde ise doğası gereği sahip olduğu olası dezavantajlar (gürültülerden dolayı görüntü kalitesi bozulmakta) ve görüntüleme yöntemlerinde birçok farklı tekniklerin kullanılması, görüntü işleme yöntemlerinin ilgili sisteme uygun olması gerektiğini ortaya koymaktadır. Ayrıca CWDOT sistemlerinde gürültüyü oluşturan; kalibrasyon hataları, deneysel hatalar ve elektronik gürültü gibi birçok neden vardır. Literatürde gürültüyü azaltmak ve tam olarak ortadan kaldırmak için birçok yöntem bulunmasına rağmen, doğruluk oranı yüksek ve görüntüleme 
yöntemine uygun filtreleme yöntemleri tasarlamak önemlidir [8-9]. Önceki çalışmalarda tasarlanan ve Şekil 1'de blok diyagramı gösterilen CWDOT sisteminde [11] farklı geri çatım teknikleri uygulanmıştı [17]. Sistemde intralipid ve simülasyon deneyleri yapılarak en uygun geri çatım tekniği TCG algoritması olarak belirlenmişti ve sistemin çalıştığı gösterilmişti [17].

Bu çalışmada kullanılan CWDOT sisteminde meme dokusu eşdeğeri ortamda (Şekil 2) in-vitro deneyler yapıldı. İlk olarak, probun hizasına getirilen inklüzyon ve/veya inklüzyonların, intralipid içinde ölçülmesi amaçlandı. İlk olarak, geri çatım tekniklerinden olan TCG algoritmasıyla elde edilen veriler, görüntü işleme öncesi elde edilerek sistem hazır hale getirildi. Daha sonra görüntü işleme yöntemlerinden literatürde sıklıkla kullanılan uzaysal filtreler; Ortalama filtreleme, Gauss filtreleme, Laplas filtreleme, LoG filtreleme yöntemleri tasarlanarak CWDOT sistemine uygunluğu test edildi. Son olarak, CWDOT sisteminden elde edilen görüntüler son haline getirilirken olası değerleri tahmin etme ve gerçeğe daha yakın görüntüler elde etme ihtiyacindan dolayı son olarak filtreleme yönteminden sonra interpolasyon yöntemleri uygulandı. Bu kapsamda, medikal görüntülemede sık kullanılan en yakın komşu, çift doğrusal, çift kübik ve kübik spline interpolasyon yöntemleri uygulandı [9, 18-19].

Kullanılan görüntü işleme algoritmalarının başarılarının değerlendirilmesi görsel olarak karşılaştırılabilir. Fakat görsel karşılaştırmalarda görsel bir yanılma olabileceği gibi, ileri görüntü işleme adımlarında karşılaştırma seçeneklerini azalmaktadır. Bu nedenle görüntü işleme algoritmaların performanslarını karşılaştırmak için bir takım nicel ölçütler kullanılmaktadır. Bu bakışla yukarıda anlatılan görüntü işleme yöntemlerinin hangi kombinasyonu CWDOT sistemine uygun olduğunu belirlemek için sayısal olarak karşılaştırmalar yapıldı. Sayısal karşılaştırmalar, PSNR, MSE ve SSIM sonuçları ile yapıldı. Genel olarak PSNR değerlerinin yüksek, MSE değerlerini düşük, SSIM değerlerinin yüksek olan görüntü işleme yöntemleri; Gauss filtreleme ve çift kübik interpolasyon yöntemleridir ve Tablo 1' de gösterildiği gibidir. Farklı filtreleme ve interpolasyon seçeneklerinde PSNR sonuçlarının fazla değişkenlik göstermediği görüldü. Gauss filtreleme yöntemi sonrası uygulanan çift kübik ve kübik spline yöntemleri ile MSE sonuçlarının en düşük değerini aldığı ve SSIM sonuçları incelendiğinde, Gauss ve LoG filtreleme sonrası uygulanan çift kübik ve kübik spline yöntemleri sonrası yüksek çıtı̆ğı görülmektedir (Tablo 1).

Bu kapsamda intralipid deneylerindeki elde edilen görüntülerde inklüzyonların gerçek konum ve şekil bilgisi kesikli çizgilerde gösterildi (Şekil 3-6). Görüntülerdeki kesikli çizgilere bakılarak inklüzyonların şekil ve derinlik hassasiyetlerinin sağlanabildiği tüm deneylerde gözlemlendi ve görsel sonuçları gösterildiği gibidir (Şekil 3-6). Ayrıca intralipid içine konulan iki farklı inklüzyonun görüntüsü elde edildi. Bu deney ile CWDOT sisteminde iki farklı inklüzyonun derinlik bilgisi ve birbirinden ayırt edilebilme gücü test edildi (Şekil 6). Çalışma kapsamında gerçekleştirilen yöntemler, MATLAB programı kullanılarak gerçekleştirildi. CWDOT sistemine özgün bu yöntemler, kullanıcıdan bağımsız, kısa sürede hesaplanabilir ve tekrarlanabilir ölçümler yapabilir niteliktedir. Yapılan deneyler sonucunda gerçeğe yakın, çözünürlüğü iyileştirilen renkli görüntüler 2B ve 3B olarak elde edildi. Gerçekleştirilen bu yöntemler ile gelecek çalışmalar için CWDOT sistemi kullanıma hazır hale getirildi. Sonuç olarak bu çalışmanın, medikal optik görüntüleme sistemlerinde görüntü işleme üzerinde çalışacak kişi ve/veya kişilere yol göstereceği düşünülmektedir. 


\section{Araștırmacıların Katkı Oranı Beyanı}

Yiğit Ali Üncü: Araştırma, Metodoloji, Yazılım, Kaynak/Materyal/Malzeme Temini

Gençay Sevim: Yazılım, Veri İyileştirme

Murat Canpolat: Kavramsallaştırma, Proje Yönetimi

\section{Destek ve Teșekkür Beyanı}

Çalışma kapsamında kullanılan MATLAB programı, Akdeniz Üniversitesi, Bilgi İşlem Daire Başkanlığı tarafından sağlanan lisansa sahiptir. Bu çalışma Yiğit Ali Üncü’ nün doktora tezinden türetilmiştir.

\section{Çatışma Beyanı}

Bu çalışmanın yazarları olarak herhangi bir çatışma beyanımız bulunmadığını bildiririz.

\section{Etik Kurul Onayı ve/veya Aydınlatılmış Onam Bilgileri}

$\mathrm{Bu}$ çalışmanın yazarları olarak herhangi bir etik kurul onayı ve/veya aydınlatılmış onam bilgileri beyanımız bulunmadığını bildiririz.

\section{Kaynakça}

[1] A. P. Gibson, J. C. Hebden, and S. R. Arridge, "Recent advances in diffuse optical imaging," Phys. Med. Biol., 50(4), R1-43, 2005.

[2] D. A. Benaron and D .K. Stevenson, "Optical time-of-flight and absorbance imaging of biologic media," Science, 259(5100), 1463-1466, 1993.

[3] D. A. Benaron, S. R. Hintz, A. Villringer, D. Boas, A. Kleinschmidt, J. Frahm, C. Hirth, H. Obrig, J. C. van Houten, E. L. Kermit, W. F. Cheong, and D. Stevenson, "Noninvasive functional imaging of human brain using light," J. Cerebr. Blood F. Met., 20(3), 469-477, 2000.

[4] B.W. Pogue and M.S. Patterson, "Frequency-domain optical absorption spectroscopy of finite tissue volumes using diffusion theory," Phys. Med. Biol., 39(7), 1157-1180, 1994.

[5] B. Chance, M. Cope, E. Gratton, N. Ramanujam, and B. Tromberg, "Phase measurement of light absorption and scatter in human tissue," Rev. Sci. Instrum., 69(10), 3457-3481, 1998.

[6] A. M. Siegel, J. J. A. Marota, and D. A. Boas, "Design and evaluation of a continuous-wave diffuse optical tomography system," Opt Express., 4(8), 287-298, 1999.

[7] R. J. Gaudette, D. H. Brooks, C. A. DiMarzio, M. E. Kilmer, E. L. Miller, T. Gaudette, and D. A. Boas, "A comparison study of linear reconstruction techniques for diffuse optical tomographic imaging of absorption coefficient," Phys. Med. Biol., 45(4), 1051-1070, 2000.

[8] R.C. Gonzalez and R. E. Woods, Digital Image Processing. 3rd ed. USA: Prentice-Hall, Inc., 2006, pp. 104-198.

[9] W. K. Pratt, Digital Image Processing. PIKS Inside. 3rd. ed. USA: John Wiley \& Sons, Inc., 2001, pp. 211-233.

[10] Z. Wang, A. C. Bovik, H. R. Sheikh, and E. P. Simoncelli, "Image quality assessment: from error visibility to structural similarity,” IEEE T Image Process., 13(4), 600-612, 2004.

[11] H. O. Kazanci, T. Mercan, and M. Canpolat, "Design and evaluation of a reflectance diffuse optical tomography system," Opt. Quant. Electron., 47(2), 257-265, 2015.

[12] S. Prahl. (2016, May 6). [Online]. Available: https://omlc.org/spectra/

[13] M. Sagawa, Y. Miyoseta, Y. Hayakawa, and A. Honda, "Comparison of two-and three-dimensional filtering methods to improve image quality in multiplanar reconstruction of cone-beam computed tomography," Oral Radiol., 25(2), 154-158, 2009.

[14] Y. A. Üncü, T. Mercan, G. Sevim, and M. Canpolat, "A new approach to image processing in diffuse optical tomography and 3-D image," 25th Signal Processing and Communications Applications Conference (SIU), Antalya, 2017, pp. 1-4.

[15] Y. A. Üncü, T. Mercan, G. Sevim, and M. Canpolat, "Interpolation applications in diffuse optical tomography system," 21st National Biomedical Engineering Meeting (BIYOMUT), Istanbul, 2017, pp. $1-4$.

[16] X. H. Zhang, R. L. Ning, and D. Yang, "Cone beam breast CT noise reduction using 3D adaptive Gaussian filtering," J. X-Ray Sci. Technol., 17(4), 319-333, 2009.

[17] T. Mercan, G. Sevim, Y. A. Üncü, S. Uslu, H. Ö. Kazanci, and M. Canpolat, "The comparison of reconstruction algorithms for diffuse optical tomography," Süleyman Demirel Üniversitesi Fen Edebiyat Fakültesi Fen Dergisi, 14(2), 285-295, 2019.

[18] R. Roy, M. Pal, and T. Gulati, “Zooming digital images using interpolation techniques,” Int. J. Innov. Technol. Manag., 2(4), 34-45, 2013. 
[19] V. Siddharth, S. H. Saeed, and H. Dua, "Image standardisation using interpolation," International Journal of Enhanced Research in Science Technology \& Engineering (IJERSTE), 4(4), 272-278, 2015. 